\title{
Opinions on the Sustainable Development of Aquaculture
}

Guillaume, Drillet; Chan, Nicole; Drillet, Zuzana; Foulsham, Angela Jane; Ducheyne, Alain; Eikaas, Hans S.; Schmoker, Claire; Hansen, Benni Winding; Lybæk, Rikke

Published in:

Journal of Fisheries and Livestock Production

DOI:

10.4172/2332-2608.1000118

Publication date:

2014

Document Version

Også kaldet Forlagets PDF

Citation for published version (APA):

Guillaume, D., Chan, N., Drillet, Z., Foulsham, A. J., Ducheyne, A., Eikaas, H. S., Schmoker, C., Hansen, B. W., \& Lybæk, R. (2014). Opinions on the Sustainable Development of Aquaculture. Journal of Fisheries and Livestock Production, 2(2), [ISSN:2332-2608 JFLP]. https://doi.org/10.4172/2332-2608.1000118

\section{General rights}

Copyright and moral rights for the publications made accessible in the public portal are retained by the authors and/or other copyright owners and it is a condition of accessing publications that users recognise and abide by the legal requirements associated with these rights.

- Users may download and print one copy of any publication from the public portal for the purpose of private study or research.

- You may not further distribute the material or use it for any profit-making activity or commercial gain.

- You may freely distribute the URL identifying the publication in the public portal.

\section{Take down policy}

If you believe that this document breaches copyright please contact rucforsk@kb.dk providing details, and we will remove access to the work immediately and investigate your claim. 


\section{Opinions on the Sustainable Development of Aquaculture}

\section{Guillaume Drillet $^{1 *}$, Nichole Chan ${ }^{1}$, Zuzana Drillet ${ }^{2}$, Angela Jane Foulsham ${ }^{1}$, Alain Ducheyne ${ }^{1}$, Hans S. Eikaas ${ }^{1}$, Claire Schmoker ${ }^{1}$, Benni $^{1}$ Winding Hansen ${ }^{3}$ and Rikke Lybæk ${ }^{3}$}

${ }^{1}$ DHI-NTU Research Center and Education Hub, 1 CleanTech Loop, \#03-05 CleanTech One, Singapore

2ZEnvironment SP, 222 Westwood Avenue, 08-10, 648355, Singapore

${ }^{3}$ Department of Environmental, Social and Spatial Change, Roskilde University, DK-4000 Denmark

\section{Introduction and Background}

It is widely acknowledged that aquaculture represents the fastest growing food sector with an annual growth of approximately $10 \%$ [1]. Given the high growth rate of this sector, we must look to achieve a sustainable long-term production for the sake of the coming generations. Here we provide our opinion whereby we emphasize the need to rely and build on existing knowledge and studies, both social and environmental, as well as increasing state-of-the-art technologies on aquaculture practices. This will help to mitigate the potential impacts not only on the environment, but also on the society at large, and will therefore ensure long-term sustainability.

The aquaculture sector is a key industry providing a valuable food source to our increasing global population. Aquaculture, however, may also be a sector of activity which has significantly negative impacts on the environment, if not carried out in a sustainable way. One issue, for example, is the mass production of formulated feed which often contains natural fish products (fish meals and fish oils). The increasing demand for aquaculture feed (and other pet-feed) generates a high demand for fish, resulting sometimes in over-fishing of important fish stocks, thus indirectly affecting the overall sustainability of other marine resources [2].

The industry is also regularly attributed to affect the natural environment drastically because of poor environmental practices. The excessive use of antibiotics, chemicals, and the intentional or unintentional destruction of important aquatic habitats such as mangroves, estuaries, and fjords; all important nursery grounds for wild fish stocks may also be generated if the industry develops without controls and regulations. Nevertheless, poor aquaculture practices may also affect nature besides the aquaculture industry itself by negatively altering aquatic resources through pollution of water bodies and sediments, inherently reducing the ecosystem carrying capacity.

A number of notable negative events have occurred over the last decades that are associated with the aquaculture sector, most markedly the cases of widespread disease outbreaks. This has challenged the aquaculture sector everywhere across a range of farmed and wild organisms. Examples include infectious salmon anemia virus (ISAV), Acute Hepatopancreatic Necrosis Syndrome (AHPNS, also known as Early Mortality Syndrome or EMS) and regular Harmful Algae Blooms (HABs) occurring worldwide, generating fish and shellfish mass mortality or aquaculture products unfit for consumption $[3,4]$. Not only are such cases difficult for the farmers from an economical perspective (bankruptcy), but they also affect local communities which rely on the production and marketing of aquaculture products. This particular societal effect is even more important in areas where aquaculture is run as a "mom and pop business" and where cash flow is a crucial parameter that is not supported by international investments such as in large aquaculture farms.

The disease control within the aquaculture industry, the socials and environmental effects that are generated by aquaculture productions can be mitigated and managed by changing the industry's habits from the initial planning stages through to the commercialization of aquaculture products. The solutions differ from one location to another, and are tied to the developmental stages of the sector in the various regions. The solutions lies in the use of adapted legal framework which should be in line with social structures and environmental conditions, and the application of Best Aquaculture Technologies (BAT) such as state-ofthe-art water treatment systems, water management tools, and means by which to firstly identify, then secondly to minimize and eliminate or mitigate disease occurrence and spread.

Stakeholders such as governments authorities, environmental companies, nature protection agencies, farmers and aquaculture associations, research institutes, not-for-profit companies, technology providers, and NGOs should ideally work together to ensure that such poor practices are an exception to the norm, and do not become the standard.

\section{Need for Adapted Legal Framework and Regulations}

To avoid the inexpedient development of the industry, which would put long-term objectives of sustainability at risk, proper decision making tools should be used whenever possible. Of these tools, some may be globally transferable while others adapted locally to address the specific needs of the natural environment and society. To this end, it is the responsibility of governments and decision-makers to ensure that relevant legal framework exists, that regulations are useful and respected, and that the approaches reflect the capacity of the industry to adapt to new relevant procedures nationally, regionally and internationally $[5,6]$. In areas where the national legal frameworks are limited or not properly enforced, the industry can leverage on examples offered by other countries as well as global certifications programs which are ultimately driven by global consumer demands for not only quantity, but also quality [7]. Thus, different certifications and labels may support the development of a quality assurance framework fostering responsible social and environmental behaviours. However, certifications and labels can only be used as a short term solution to reach better practices in some of the farms working toward exportation of productions but have eventually to be replaced by a proper and enforced legal framework to ensure that best practices are generalized on all the productions.

\section{Importance of Social and Ecological Baselines}

Productions (not only aquaculture), while having an influence on the natural ecosystem structure and functioning, do not necessarily always imply a loss of diversity or function. On the contrary, in some

*Corresponding author: Dr. Guillaume Drillet, DHI-NTU Research Center and Education Hub, 1 CleanTech Loop, \#03-05 CleanTech One, Singapore, E-mail gdr@dhigroup.com

Received October 11, 2014; Accepted October 21, 2014; Published October 31 2014

Citation: Drillet G, Chan N, Drillet Z, Foulsham AJ, Ducheyne A, et al. (2014) Opinions on the Sustainable Development of Aquaculture. J Fisheries Livest Prod 2: 118. doi: 10.4172/2332-2608.1000118

Copyright: $\odot 2014$ Drillet G, et al. This is an open-access article distributed under the terms of the Creative Commons Attribution License, which permits unrestricted use, distribution, and reproduction in any medium, provided the original author and source are credited. 
cases, extensive management may become a source of high biodiversity [8] while abandoned farmed areas depict a loss of biodiversity [9]. By environmental impacts, we mean not only biodiversity shift as an exhaustive list of species present or absent from ecosystems but rather a combination of impacts on the environment and the society.

Aquaculture as a key industry supporting the economy is relatively new in some regions of the world. Interestingly, aquaculture is not perceived the same way in areas where it has had a long-term persistence as compared to areas where it has been limited to a few niche products responsible for small economy. This presents a good example showing how strongly we are affected by our own perception whereby points of reference change over time and place, an important consideration when establishing a conservation baseline [10]. Extensively managed land farming habitats are recognized as socially important and are supported financially in many countries because they are considered as a traditional, cultural, and natural heritage. We believe that aquaculture will also, in due time, be part of the 'conservation baseline'. However, in order to achieve such a standing, the industry first has to prove that this food production is sustainable by ensuring that the environmental carrying capacity is not exceeded, causing defined negative environmental impacts, and also by ensuring a good quality and quantity of product along the entire production chain.

\section{Planning and Impact Assessments}

In terms of environmental planning and management, we support the idea that whenever possible, formal Environmental Impact Assessment (EIA) should be carried out prior to development of new productions as well as around existing productions where environmental management has not been undertaken or not applied properly. These studies could help ensure that the impacts generated by future productions would not affect the environment in such a way that the resources would be permanently depleted, or the ecosystem function is not dramatically or adversely affected, or unable to recover post-production (if ever discontinued).

In aquaculture, considering finfish, shellfish, as well as other nonfish species, a formal EIA should include consideration of the existing environmental baseline as a basis for the assessment of scenarios for production including type of farmed organisms, quantity and production systems used, resource usage, as well as the more familiar and well-known environmental challenges such as nutrient loading. In particular, environmental assessments of facilities should be analysed and compared to the evaluated carrying capacity of the ecosystem to ensure sustainability [11]. Moreover, a thorough risk assessment covering aspects such as disease, parasites, genetic pollution, etc. should be mandatory. Further, technologies to be implemented should be assessed within a management framework where the environmental carrying capacity is evaluated; this should include whether other types of agro-industry could be connected to the specific aquaculture production (such as mechanical and chemical water treatment, or the use of aquaponics). Such studies are challenging because of the cumulative and often irreversible nature of such impacts and the multiple users with overlapping and conflicting demands on the resources within any given area. This implies that one must evaluate all other sources of alteration for the particular environment to categorise those related to the aquaculture development alone, differentiating them from other impacts and make informed value judgements before arriving at any range of possible solutions and conclusions. Other users of the water resource, such as other aquaculture farms, industries, ports and shipping, tourism developments, and local inhabitants, should be entitled to use the resource sustainably, and this is commonly regulated through practices such as Integrated Coastal Zone Management
(ICZM), covering both the marine and terrestrial interfaces in question. We do believe that this is a proper approach to sustainability, but this is a wider planning tool and not only to be managed by aquaculture stakeholders $[12,13]$.

Nevertheless, aquaculture stakeholders and farmers sharing common resources should first initiate and then take part into Aquaculture Zone Management Programs (AZMP), where after the signature of an agreement or memorandum of understanding (MOU), a minimum of information sharing about the state of their production, nutrient discharge and disease control may be used to ensure beneficial consistency of management throughout all sites, that the carrying capacity of the ecosystem is not exceeded, and that in the event of breakout of disease spread, can be controlled. These types of programs may be occasionally costly and not necessarily easy to put in place, but they protect the industry from negative environmental issues from an early stage, and help to develop and share a common communication line with both neighbours and consumers alike. On a day-to-day practice, farmers taking part in AZMP can share information through databases and geographical web-based /mobile tools to visualise in real time, or in forecast mode, the water quality of their production sites (e.g. Decision Support Systems (DSS)). Early and integrative spatial planning tools used in ICZM and AZMP allow for efficient use of space, but also ensure that new or existing developments do not damage crucial ecological habitats.

\section{Use of Technologies}

The aquaculture industry needs to guarantee its sustainable future development by ensuring that the consumer demands are respected, while respecting the societal and environmental needs. We believe that in implementing new procedures and approaches, which address both practical and economic issues, the industry will grow sustainably without being limited by environmental and societal constraints. We support the rapid and intelligent implementation of state-of-the-art BAT ensuring cleaner and safer production [14]. Whether the productions are situated on land or at sea, there is a possibility to integrate water treatment systems and protocols to improve the quality of the water used in production as well as quality of the effluent discharged back in the environment (sludge and nutrient removal). Water discharges containing nutrients, such as phosphorus and nitrogen, can also be utilized as fertilizers to support additional production of crops for human or animal consumption, possibly in aquaponic systems where no soil is needed [15]. This would reduce the environmental impacts of the primary aquaculture production and create synergies to new products, and thus additional employment opportunities.

Nevertheless, water treatment systems used may well be driven one more level up in terms of control by generalising the use of recirculated aquaculture systems (RAS), where the same water is used again, recirculated, and continuously rinsed in the production system. Fully recirculated systems may re-use $90-95 \%$ of the water in the farm minimizing the volume discharged [16]. However, such systems may not be needed in areas with good water resources and optimal water quality, and where the production site and size have been planned properly to ensure that the carrying capacity of the environment is not reached. In such areas, less advanced technological solutions might be sufficient to obtain an environmentally acceptable aquaculture production.

\section{Conclusions and Future Developments}

Finally we advocate that investment in research is crucial to diversify the number of species raised in aquaculture production; this should be done through the improvement of live feed technologies and 
feeding protocols [17]. The investment in research and development should also focus on fish-meal and fish-oil replacement as well as in water treatment and RAS technologies. Innovations in areas such as agricultural production, additional to the aquacultural aspects, must be emphasized to develop synergies and align processes. Moreover, governments and other decision-making and regulating bodies must require implementation of suitable environmental assessment and management, including the appropriate application of BAT, according to analysis of the environmental carrying capacity in the local context. Though legal frameworks and their enforcement are the responsibility of governments, stakeholders are also to play their respective roles, avoiding the trap of focusing on tomorrow's gain while ignoring the day after tomorrow's pain, where struggles will emerge if we do not think thoroughly about the sustainability of our growing industry and society.

\section{Acknowledgement}

This work is supported by the Elite Forsk grants 10-093759 and 10-094773 from the Danish Agency for Science Technology and Innovation to GD and the Strategic Research Council of Denmark IMPAQ grant (j. no. 10-093522) to BWH. We are also thankful to the DHI-NTU Research Centre and Education Hub.

\section{References}

1. FAO (2014) The state of world fisheries and aquaculture. Food and agriculture organization of the United Nations: Rome.

2. Huntington $T$ (2009) Use of wild fish and other aquatic organisms as feed in aquaculture-a review of practices and implications in Europe. Fish as feed inputs for aquaculture: practices, sustainability and implications.

3. Eng CT, Paw JN, Guarin FY (1989) The environmental impact of aquaculture and the effects of pollution on coastal aquaculture development in Southeast Asia. Marine pollution bulletin 20: 335-343.

4. Shumway SE (1990) A review of the effects of algal blooms on shellfish and aquaculture. Journal of the World Aquaculture Society 21: 65-104.

5. Bashirullah A, Mahmood N, Matin A (1989) Aquaculture and coastal zone management in Bangladesh. Coastal Management 17: 119-127.
6. Tacon AG, Forster IP (2003) Aquafeeds and the environment: policy implications. Aquaculture 226: 181-189.

7. FAO (2011) Private standards and certification in fisheries and aquaculture Curent practice and emerging issues. FAO Fisheries and Aquaculture technical paper 553: 181.

8. Ihse M, Lindahl C (2000) A holistic model for landscape ecology in practice: the Swedish survey and management of ancient meadows and pastures. Landscape and Urban Planning 50: 59-84.

9. Imrichova Z, Vrahnakis M (2005) Revealing changes in biodiversity pattern by means of PTFs. Integrating efficient grassland farming and biodiversity. Tartu: Greif printhouse, 2005: 128-132.

10. Pauly D (1995) Anecdotes and the shifting baseline syndrome of fisheries Trends in Ecology \& Evolution, 10: 430.

11. Wu RSS (1995) The environmental impact of marine fish culture: towards sustainable future. Marine pollution bulletin 31: 159-166.

12. Buschmann AH, López DA, Medina A (1996) A review of the environmental effects and alternative production strategies of marine aquaculture in Chile. Aquacultural engineering 15: 397-42.

13. Primavera $J(2006)$ Overcoming the impacts of aquaculture on the coastal zone. Ocean \& Coastal Management 49: 531-545.

14. Klee P, Heldbo J, Birkeland MJ (2014) Rethinking aquaculture to boost resource and production efficiency; Sea and land-based aquaculture solutions for farming high quality seafood. In: The Rethink Water Network \& Danish Water Forum 2014

15. Rakocy JE, Masser MP, Losordo TM (2006) Recirculating aquaculture tank production systems: Aquaponics-Integrating fish and plant culture. SRAC publication 454: 1-16.

16. Martins C, Eding EH, Verdegem MCJ, Heinsbroek LTN, Schneider O, et al. (2010) New developments in recirculating aquaculture systems in Europe: A perspective on environmental sustainability. Aquacultural Engineering 43: 8393.

17. Drillet G, Frouel S, Sichlau MH, Jepsen PM, Hojgaard JK, et al. (2011) Status and recommendations on marine copepod cultivation for use as live feed. Aquaculture 315: 155-166.
Citation: Drillet G, Chan N, Drillet Z, Foulsham AJ, Ducheyne A, et al. (2014) Opinions on the Sustainable Development of Aquaculture. J Fisheries Livest Prod 2: 118. doi: 10.4172/2332-2608.1000118
Submit your next manuscript and get advantages of OMICS Group submissions

Unique features:

- User friendly/feasible website-translation of your paper to 50 world's leading languages

Audio Version of published paper

Digital articles to share and explore

Special features:

350 Open Access Journals

30,000 editorial team

21 days rapid review process

Quality and quick editorial, review and publication processing

Indexing at PubMed (partial), Scopus, EBSCO, Index Copernicus and Google Scholar ete

Sharing Option: Social Networking Enabled

Authors, Reviewers and Editors rewarded with online Scientific Credits

- Better discount for your subsequent articles

Submit your manuscript at: http://www.omicsonline.org/submission/ 